\title{
„Egyik sem jár az ördögséggel, édes jó Uraim” - Boszorkány-kihallgatások kommunikációs kontextusáról
}

1. Bevezetés. Az alábbi esettanulmány témája a boszorkányperekben megragadható kommunikációs stratégiák - nyelvi viselkedésbeli lehetőségek és megvalósulási mintázatok - kontextusának feltárása, különös tekintettel a boszorkányok elleni peres eljárásbeli szerepek és a hozzájuk kapcsolódó diskurzusstratégiák kérdéskörére. A vizsgálat anyaga egy Szolnok megyei bizonyítási eljárás, kitekintésként további kihallgatási szövegeket bevonva az elemzésbe. A Szolnok megyei peranyag választását az összetett interakció indokolja. Az eljárás több boszorkánysággal vádolt személyt érint, a tanúbizonyítást pedig egy szembesítésnek tekinthető kihallgatás követi, ennek során a vádlottak a kihallgatást végző személyek mellett tanúkkal is kommunikálnak.

A kutatás egyaránt foglalkozik a diskurzusszerveződéssel és kontextus-konstruálással (történeti anyagon); valamint az önreprezentáció vagy benyomáskeltés ${ }^{1}$ kérdéskörével (NEMESI 1997; 2000; boszorkányperes tanúvallomások alapján VARGA 2015). Ez utóbbi szempontot az indokolja, hogy a boszorkány egy olyan szerepként (nem pedig személyként) értelmezhető, amely részben ideológiából, részben viselkedésből áll (lásd pl. Pócs 1983; KLANICZAY 2014; Sz. KRISTÓF 2014). A jellegzetesnek tartott viselkedésbe - magyar források alapján mindenképpen - beletartozik a nyelvhasználat is, ennek egyes aspektusai a tanúvallomások szövegeiben is megragadhatók. A vizsgált anyagban ugyanakkor a vádlottak megnyilatkozásai is hozzáférhetők (ha közvetett módon, a lejegyzőkön keresztül is). A boszorkányszerep nyelvi jellemzői ezúttal egy olyan szituációban írhatók le, ahol a megnyilatkozók viselkedésének különösen tétje van. E kérdéskör kapcsán párhuzamként tekintetbe vehetők a salemi peranyagok (1692-1693), mivel egyrészt jelentős számú szöveget tartalmaznak, másrészt az itt tárgyalt kérdéskört tekintve a szakirodalomban ezek vannak a legrészletesebben feldolgozva. Harmadrészt azzal indokolható a párhuzam, hogy a salemi ügyek esetében - kimenetelük alapján legalábbis - valamiféle tényleges boszorkányságként azonosítja a hatóság a vádlottakhoz kapcsolt cselekedeteket a saját időszakukban (az itt vizsgált szövegekhez hasonlóan, bár a magyar anyagban ezek a cselekedetek változatosabbak). Ráadásul e peranyagok alapján már ismeretesek jellegzetes vádlott-típusok

*A tanulmány az 116217 számú OTKA-munkálat anyagait felhasználva, az Emberi Erőforrások Minisztériuma ÚNKP-17-3 kódszámú Új Nemzeti Kiválóság Program támogatásával készült.

${ }^{1}$ A mindenkori megszólalóban tetten érhető egyfajta igyekezet, hogy befolyásolja a másoknak szánt kifejezések tartalmát és stílusát - ezt az élőnyelvi megnyilatkozásokra és viselkedésmozzanatokra jellemző tényezőt nevezi a szociálpszichológiai szakirodalom benyomáskeltésnek (vö. NEMESI 1997: 491-492, 2000:418-421). Ebben a felfogásban a mindennapi társalgás során előkerülő viselkedési helyzetek a szerepjátszás metaforájának segítségével értelmeződnek (alakítás, az aktuális csoport jelenlétéhez kötődő tevékenységek együttese stb.).

Magyar Nyelv 114. 2018: 411-427. DOI: 10.18349/MagyarNyelv.2018.4.411 
és a hozzájuk kapcsolódó stratégiák (KAHLAS-TARKKA-RISSANEN 2007, 2011; KAHLAS-TARKKA 2012; RISSANEN 2012; KAHLAS-TARKKA-RISSANEN 2015). Ezek az elemzések olyan szempontokat adnak a jelen kutatáshoz, mint az udvariasság/udvariatlanság, a verbális agresszió, a társadalmi nem. A jelen vizsgálatban lényeges még a kérdezők szerepe a kihallgatások során, valamint a lejegyzés egyes aspektusaira is érdemes kitérni (lásd 3. pont).

A vizsgált szövegek számos pragmatikai jelenségre irányították a figyelmet: egyrészt fontos, hogy milyen közösségi boszorkánykép, boszorkánysággal kapcsolatos attitüd rajzolódik ki a korábbi bizonyítás és ezeknek a kihallgatásban felidézett eredménye alapján (szubjektív, érzelmi-indulati megnyilvánulások, értékelő megjegyzések, történetbeli fordulatok, akár a tanúk felidézett reakciói). Szempont továbbá a kérdezőkkel való együttmüködés és annak dinamikája mind a tanúk, mind a vádlottak részéről (részletesen lásd 2. pont). Dinamikus elemzést igénylő jelenségekről lévén szó, szoros olvasás alapján mutatom be az eredményeket.

\section{Megközelítés: „Szükszavúak és beszédesek”. A salemi stratégiák át-} tekintése. A salemi anyag diskurzusstratégiáit feltáró korábbi kutatások a szinkrón nyelvi anyagra kidolgozott ( $\mathrm{s}$ a hatalmi viszonyokkal is összefüggésben levő) udvariassági elméletekre és az együttmüködési elvre épültek (KAHLASTARKKA-RISSANEN 2007; KAHLAS-TARKKA 2012; RISSANEN 2012; KAHLASTARKKA-RISSANEN 2015). Az általános beszélő-hallgató viszonnyal kapcsolatos elméleteket és modelleket - beleértve a társalgási maximákat és az udvariasság felfogását is - ugyanakkor nem tekinthették elégségesnek a kutatók (KAHLASTARKKA-RISSANEN 2007: 3; RISSANEN 2012: 120). Noha a salemi anyag kapcsán a grice-i maximák modelljét a kutatók egy része közvetlenebb módon is tekintetbe veszi (CHAEMSAITHONG 2009: 74-79), a jelen vizsgálatban ennek a modellnek a követése több szempontból is problematikus lenne. CHAEMSAITHONG maga is egyszerre többféle modellben kezeli az adatokat, ezért azt állítja, nincs példa arra, hogy a szükségesnél kevesebb információt szolgáltatnak a vádlottak (2009: 74), miközben a szükszavú „,nem tudom” típusú válaszok és a „csenddel válaszolás” eseteit is megtaláljuk az anyagban. Ezeket azonban más kategóriában, az arcfenyegetés hárításaként kezeli, nem a hozzájárulás információtartalma szerint (míg a komplexebb értelmezést igénylö iróniát igen), az azonban nem derül ki, hogy a két modell egymással milyen viszonyban van (CHAEMSAITHONG 2009: 77).

A középmagyar korszakkal kapcsolatos (,teljes körü”) pótkompetencia híján közel sem egyértelmü, hogy akkoriban egy kihallgatás alatt mit tekintettek szükséges, túl sok vagy túl kevés információnak - ha épp nem reflektálnak rá a jegyzőkönyv szerint. Az egyes helyeken megtalálható reflexiók nem feltétlenül általánosíthatók. Nehéz lenne azonosítani, mikor túl sok az információ, hiszen a tanúkat mindig a körülmények szerinti megvallásra szólítják fel, s olyan történeteket is lejegyeznek, amelyekre nem kérdeztek rá (s természetesen a kérdéseket implicit módon össze is vonhatták). További probléma, hogy a mennyiség maximájának feltűnő megsértése szükségszeren, például a minőség maximájának betartása érdekében történhet (ha egyszer a tanú vagy a vádlott nem rendelkezik általa igaznak tartott és kellően releváns információval). Felmerül tehát az a módszertani 
kérdés, hogy a stratégiák egy-egy (szinkrón) szempont szerint történő besorolása mennyit árul el az adott stratégia müködéséről történeti anyagon.

A szinkrón modellek inkább kiindulópontként kezelését az is indokolja, hogy a vizsgált személyek megnyilatkozásait alapvetően nem az elöre meghatározott konvencionális kritériumok alakították, hiszen kommunikációjuk célja elsődlegesen az volt, hogy a saját életüket mentsék (vö. KAHLAS-TARKKA-RISSANEN 2007: 3; 2015: 153-154; HILTUNEN 2010). A hagyományos modell szerint az együttmüködési elv azt jelenti, hogy a megnyilatkozó és a befogadó erőfeszítéseket tesz annak érdekében, hogy a társalgásbeli céloknak és elvárásoknak megfelelővé tegye hozzájárulását - a vádlottak kihallgatásának szituációjában ez olyan elvárásként fogalmazódik meg, hogy a vádlott az adott kérdés kapcsán minél több részletet szolgáltasson (KAHLAS-TARKKA-RISSANEN 2007: 3-4).

A salemi peres eljárások során - a kutatások alapján - az előfeltevés az volt, hogy a vádlott bűnös, de nem akarja beismerni. Ebből a nézőpontból a távolító (azaz a másik fél függetlenségét tiszteletben tartó) udvariassági stratégiák számítottak eredményesnek. A kutatók az alábbi fó elveket emelik ki: 1. az adott kérdés kapcsán minél több részletet szolgáltatni, föként ha az másokat is érint; 2 . elismerni, amivel megvádoltak, de azt tagadni, hogy szándékosan bántott másokat; 3 . nem vitatkozni a kérdezővel; 4. segíteni további boszorkánysággal gyanúsítható személyek azonosításában (KAHLAS-TARKKA-RISSANEN 2007: 5-10; RISSANEN 2012: 120). Eredményes stratégia volt, ha a vádlott hangsúlyozta a saját vétkes szerepének kicsinységét, inkább másokra (akár az ördögre) hárítva a káreseteket, vagy hangsúlyozva, hogy nem a maga ura volt, hanem egyfajta rontás vagy fenyegetés alatt állt. Az egyik kihallgatott például a vallomástétel során úgy viselkedik (a lejegyzés alapján), mintha épp az ördöggel küzdene, mintha az nem hagyná beszélni. Azzal ugyanis, hogy beismerés közben „gyötri az ördög”, szánalmat is kiválthatott (KAHLAS-TARKKARISSANEN 2007: 5-10). Ezzel együtt az alapvetően bünbánó attitüd kimutatása része volt az együttmüködésnek. Az együttmüködés fokozatokban, skalárisan értelmezhető, nem minden elv, lehetőség következetes alkalmazását jelenti.

A később halálra ítélt vádlottak vallomásaiból a felsorolt (célravezető) stratégiák ellentéte rajzolódik ki a kutatók szerint (KAHLAS-TARKKA-RISSANEN 2007: 10-14). Annak ellenére, hogy a tagadás sikertelen megoldásnak számított, (beleértve a vád visszautasítását, hogy bármilyen boszorkánysághoz köze van), többen is kitartottak emellett, megkérdőjelezve a bizonyítékok hitelességét vagy a kérdezők, vizsgálók bölcsességét, igazságosságát. Az ítéletek alapján nyílt arcfenyegető gesztusnak tekinthető a kutatók szerint a képletes fordulatok (ártatlan, mint a frissen hullott hó stb.), Isten és Krisztus emlegetése (azzal összefüggésben, hogy ők tehetnek igazságot, nem a hatóság), a retorikai kérdések, a kérdezők, tanúk utasítása, tanácsokkal ellátása (vö. „,ne engem kérdezzen”), az irónia, szarkazmus, a nevetés. Szintén nem volt bizonyító értéke annak, ha a vádlott vallásosságát, feddhetetlen életét, közösségbeli szerepét hangsúlyozta (KAHLAS-TARKKA-RISSANEN 2015).

3. Lehetőségek és korlátok. A magyar boszorkányperes ügyek esetében nem feltétlenül maradtak fenn a vádlottak kihallgatási szövegei az ítélettel együtt, így nem minden esetben egyértelmü, hogy milyen eredménnyel zárult az eljárás 
(lásd még Sz. KRISTÓF 2014: 38-40). Az sem példátlan, hogy - a közlés alapján az ítélet ugyan fennmaradt, de az bizonyítás korábbi anyagai (tanúkihallgatás, a vádlott kihallgatása) nem hozzáférhetők. Alapvetően tehát nem rendelkezünk minden eljárásról annyi információval, mint a salemi anyag kutatói. ${ }^{2}$ Salem abban a tekintetben is közvetett párhuzam, hogy az ismert ítéletek és kihallgatási szövegek alapján határozottabb körvonalú kép rajzolódik ki a kérdésről (az ottani üldözés egy viszonylag rövid időszakot és zárt közösséget érint). A magyar forrásokból kiindulva ugyanakkor egyelőre nem állapíthatjuk meg azt, hogy egyetlen jól meghatározható viselkedési stratégia mindig felmentést eredményezne, még akkor sem, ha „csak a valódi” boszorkányperekkel foglalkozunk, az úgynevezett becsületsértési ügyekkel nem. Mivel további hasonló kutatások más területek és boszorkányperes források esetében egyelőre nem ismeretesek, elsősorban a salemi anyagból kirajzolódó stratégiákat veszem tekintetbe az összevetéshez, ezeket azonban nyitottan, azaz nem elvárásként, hanem lehetséges mintázatként kezelve, egyaránt számítva hasonlóságokra és eltérésekre (szem elött tartva a társadalmi-kulturális különbségeket is). A jogtörténeti megállapítások mellett (utóbb lásd KoNCZ 2007: 196, 207209) ugyanis igazolhatók szövegszerủen olyan viselkedésmódok, amelyek enyhébb büntetést eredményeztek - a fennmaradt ítéletek, összefoglalók alapján is.

Annyi bizonyos, hogy szövegszerủen nem igazolódnak az olyan megállapítások, mint például egyes angol boszorkányüldözések esetében (vö. CULPEPERSEMINO 2000: 110), ahol a megvádolás a boszorkányság mint tevékenységtípus azonosításával egyenértékü (a hazai boszorkányokhoz ráadásul különböző tevékenységtípusokat kapcsol a hiedelem, vö. Sz. KRISTÓF 2014: 31-32, 37-38). ${ }^{3}$ A magyar források alapján ugyanis nem feltétlenül bizonyosodik be cáfolhatatlanul a boszorkányvád. Ez azzal együtt is igazolható, hogy a halálra ítéltek nagyságrendjének megítélése bizonytalan: az ismert ítéleteknek mintegy 51\%-a ilyen, ez az összes manapság feltárt ügyhöz viszonyítva azonban az esetek mintegy $18 \%$ át fedi le; az egy-egy területre vonatkozó arányok szintén változatosak (vö. Sz. KRISTÓF 2014: 39-40). Ennek ellenére természetesen indokolt az a kérdés is, hogy a vádlott megnyilatkozásainak volt-e bármilyen hatása az ítélet kimenetelére.

Előfordult, hogy a vádbeszéd, az indítvány szerint a vádlott halált érdemelt (például Halász Ilona esetében), ${ }^{4}$ 1769: elevennyen tüzre itéltessék, porrá hamuvá tétessék (Bosz. 2: 225. sz.). Noha az idézett részlet formulának is tekinthetö, a boszorkányság vádjával kapcsolatos hozzáállás, a legsúlyosabb büntetések indokoltnak tartása egyértelmüen következik belőle. A tanúk és a vádlott kihallgatása után

${ }^{2}$ Az alábbi honlap a magyarországi boszorkányperek adatait gyűjti össze, azonban az ítéletek közel sem mindig hozzáférhetők (értelemszerűen a fennmaradt források nyomán lehet minden esetben kikövetkeztetni): http://www.vmmuzeum.hu/boszorkanyperek.

${ }^{3}$ „Clearly once an accusation had been made and the judges had instantiated the witchcraft activity type, the accused would find very difficult to disprove the accusation" (CULPEPER-SEMINO 2000: 110).

${ }^{4} \mathrm{Az}$ adatokat a szövegek alapján betűhủen közlöm, a hivatkozás az évszám mellett a perek száma alapján történik. A szövegek elektronikusan is hozzáférhetők az alábbi adatbázisból: http:// tmk.nytud.hu/ (a korpuszról lásd DöMÖTÖR et al. 2017). A korpuszba még nem került forrásokra a forrás rövidítése és az oldalszám alapján hivatkozom. 
azonban az ítélet épp ennek ellenkezője lesz, felmentés: szenvedése [...] elégnek itéltetik; azért szabadon eleresztetik. A vádlott elismeri, hogy az általa alkalmazott „kezelés” után meghalt a gyermek, azonban hangsúlyozza, hogy nincs közvetlen összefüggés az ő cselekedete és a későbbi haláleset között: egyéb éránt is nyomorultt és beteges vala. Hangsúlyozza továbbá az ártó szándék és az esetet megelőző konfliktus (= a boszorkányi szerep) hiányát, az általa alkalmazott eljárást pedig nyomatékosan a közösségi népi gyógymód részeként írja le: más Aszszonyoktúl azt hallottam. Ez utóbbit a tanúk is megerösítik: másokis követni szokták [...] sött inkáb más Aszszonyokanak javallásabul.

A fenyegetés, káromkodás, szitkozódás, beismerése is járhat enyhébb büntetéssel - inkább a közhangulat csillapítására, $\mathrm{s}$ természetesen elrettentő példaként. 1659: ,inseralt bizonsagok uallasibul constalnak az Inak [= vádlottnak] hol mi fenegetözesi, es egyeb hasonlo babonaskodásy: De minthogy azokért Capitalis büntetest nem erdemel, Annak okaert kemennyen megh veszöztetik, es ex vinculis ki bocsatatuan az Dominus Magistratus Tartomanyabul ki üzetik” (Bosz. 2: 242. sz.); 1723: ,gonosz cselekedetei főkép masokat megh fenyegetvén, és rajtok vesztések és sebek történtek, kik miat az helység Lakosait el is remitette; noha mind ezekért halalt, ugy több dolgaiért érdemlett vólna; de tekintetben vétetődvén régi raboskodása: azért az élete ugyan el engedődik, de az Nemes Varmegyébül ki csapattatik" (Bosz. 1: 63. sz.). A beismerés hiánya is eredményes lehet: 1750: „Mint hogy a Raboskodó Aszony a Csigazást ki szenvette; és semmit sem vallot, az előbbeni feslet életéért pedigh és káromkodásáért az eddigh való szenvedése elégnek találtatik, azért föll szabadéttatik, és ell bocsattatik" (Bosz. 1: 224. sz.).

A diskurzusstratégiákat tekintve van példa arra, amikor a Salemben eredményes attitüd mutatkozik meg - az ottanitól teljesen eltérő eredménnyel: A vádlottól (Hampo Örzse) rögzítenek beismerő válaszokat arra vonatkozóan, hogy mivel gyógyított, ki tanította, valamint 1737: maga roszul lévén, kérte tanitaná (Bosz. 1: 219. sz.). Ezzel egyúttal név szerint is megvádol valakit: s innét tudgya hogy boszorkány vólt Pálfi Ilona. A kihallgatás során felidézett történetekben hangsúlyozza, hogy milyen csekély szerepe volt a boszorkányos társaságban és tevékenységekben: jelen volt ugyan, de eö pedig az ajton kivül maradot; sőt kérte Ilonát ne bántaná Mártint; ez nem mehetet még eddig; Az igaz élö Istent ez még meg nem tagatta, Az ördöggel ennek pedig nem vólt közö. A rontásokat (olykor még a fenyegetést is) tehát tagadja, ezeket állítása szerint mindig Pálfi Ilona követte el: ez fenyegette megh, de ugyan csak Pálfi Ilona ment hozzá. Ráadásul a vádlott boszorkánytársa miatt nem tudott a vádlott korábban vallomást tenni: Ezeket azért ki nem vallotta elöb hogy Ilona fenyegette meg rontással; csak kinynyában vallott némelyekre hogy Társai lettek vólna; de lelkire nem veheti eőket. A tanúvallomásokban a szerepek különbségének kevés nyoma van: az említés legalábbis mást tükröz: „ugyan boszorkánynak társához”. Kivételesnek számít, hogy a vádlott ajánlatot is tesz az egyik kárvallott meggyógyítására: Az Inquisitioban emlétet legin férre vont szájátis meg tudná gyogyetani ha meg szabadulhatna, ezerjó füvel, és innyujtó füvel, meg fözvén meg gözölné véle. A vádak másra hárítása (bár egyfajta tagadásnak is tekinthetnénk) nem járt sikerrel.

A fennmaradt ítéletek szerint alapvetően a vádak tagadása, a bünösség el nem ismerése járt enyhébb ítélettel vagy akár felmentéssel is. 1723: ,az kit Törvény előtt 
tagad [...] mindazáltal, hogy magát emitt amott javítsa, 20 Pálcza ütésekkel [...]" (SUGÁR 1987: 94); 1726: „ha saját tagadásához önként ragaszkodik, ő ezen vármegyék kebeléből számüzetik" (SUGÁR 1987: 110). Egyes esetekben azonban a tagadás nem eredményez enyhe ítéletet: időnként a tanúk beszámolója befolyásolja a döntést (bár a vádlott viselkedésére csak utalnak a szövegben: Bosz. 2: 415. sz., 1740).

Különbség mutatkozik a között is, hogy a tagadás nyílt, direkt vagy indirekt módon valósul meg. Linka Mária például arra utal az egyik tanú rosszullétével kapcsolatban, hogy nem komolyan mondott valamit, 1755: és én nevettem rajta (Bosz. 1: 95. sz.). Feltehetően arra próbált ezzel célozni a vádlott, hogy nem ő tehetett a dologról, vizsgálók számára azonban ez éppen támadási felületként kínálkozik: Tehát keresztény Embernek nevetni kely az ollyatin szerencsétlenséghén felebaráttyának? Az egyezkedés jegyében a vádlott rögtön visszakozik. Ecseri Annánál pedig a vád tagadása fogalmazódik meg indirekt módon, 1750: Akkor mondottam néki. Kjend ne gyanakodgyon reám mert bizony meg bánnya, és soha többe meg sem gyogyitom, s megis haragudtam reá az eö beszédéért; [...] és én eleget mondottam néki hogy ne mondaná azt mások elött (Bosz. 1: 100. sz.). Ezt a közvetett tagadást (akár a benne foglalt fenyegetés miatt) azonban a vizsgálók a beismeréssel egyenértékünek értelmezhettek.

A jelen vizsgálat kérdése a fentiek ismeretében az, hogy a tagadást megvalósító különféle diskurzusstratégiák milyen viszonyban állnak a salemi vádlottak megnyilvánulásaival; oly módon fejezik-e ki a tagadást, mint a salemi (később elítélt) vádlottak, vagy inkább a beismerőkhöz hasonló - együttmüködő - benyomást keltenek (a bünbánó attitüd ebben a formában nyilván nem kérhető számon). A salemi peranyagokból nem derül ki, hogy megkülönböztették-e az ún. ,jóindulatú" vagy „önkéntes” vallatást (benignum examen vagy benevolum examen) a kínvallatástól (tortura). Az udvariatlanság és a verbális agresszió különböző megnyilvánulásai nagyobb valószínűséggel köthetők az előbbi típusú kikérdezéshez (bár ez sem jelentett kényszer nélküliséget, vö. KonCZ 2007: 194-196). A magyar a kínvallatások eredményei a ,jóindulatú” vallomástól eltérő szerkezetüek: sokszor nincs lejegyezve explicit módon a kérdés, így nem alakul ki interakció sem; időnként inkább a tanúvallomásokhoz hasonlítanak (kérdőpontokra reflektálnak); de összefüggőbb, összefoglaló formában is fennmaradhatott.

A szembesítést is tartalmazó peranyagban az ügy is összetett: a tanúkihallgatás mellett találunk beszámolót a tárgyi bizonyítékok gyüjtéséről és az eredmény leírásáról, ezenkívül hozzáférhető a szembesítő (,jóindulatú”) kihallgatás, a vízpróba és a mázsálás összefoglalása. Némáné, Bangó és Hős Panna esetében mindegy három hónappal a szembesító vizsgálat után egy további kihallgatást tartanak. Hős Annát reverzális levél mellett szabadon bocsátják, a többi ügy kimeneteléről további forrásaink nincsenek (lásd még KLANICZAY 2014: 297).

Az elemzés során mindenképpen tekintetbe kell venni a vizsgáló személyek (szolgabíró stb.) attitúdjét a kérdések formája alapján. A vizsgálók hatalmi fölényét mutatják a felszólítások, a kételkedést, lebecsülést kifejező diskurzusjelölők (az angolban tipikusan a well, a why és a now, RISSANEN 2012: 119-120). Magyar anyagon külön érdemes figyelni arra, hogy viszonylag semleges attitüd mutatkozik-e meg a (nyitott) kérdésekben, esetleg reflektálnak az előző válaszokra is (nem 
feltétlenül szigorúan követve a kérdőpontok szokásos sorrendjét), vagy éppen tényként kezelik a feltett kérdést, már-már állításként (esetleg egy részét előfeltevésként) megfogalmazva, illetőleg jelezve, hogy a vádlottnak változtatnia kellene a korábbi vallomásán. Linka Mária kihallgatásakor például a kérdező újabb motívumként mellette szóló tanúk megnevezését várja el, 1755: „Hát mégh vane több bizonyságod?" (Bosz. 1: 95. sz.); Tehát ez nem tudgya az ejjeli Cselekedetidet, következendö képpen annyira bizonyságh nem lehet. Emellett nem is annyira kérdéseket tesz fel, hanem tényként kezelt vádpontokat: Haszontalan tagadod mikor bizonyságh sok vagyon arrúl? - Hát Gyógyitottále? Nem. Nem igaz mert te rontottad megh a Gattyás Leanyát. A szembesítés során általában a kérdezők irányítják a diskurzust, időnként azt implikálva, hogy a vádlott változtassa meg vallomását, mert van ellene bizonyíték: 1734: De Patai Pál nem ugy mondgya ám (Bosz. 2: 346. sz.). Máskor az információ forrását megelőlegezik a kérdésben, ezzel a későbbi olvasó figyelmét is irányítva: 1734: Azt halyuk: hogy a kigyok igen engednek a kgd szavanak bokorbul ki hivja, fára fel küldi, le hivja és el küldi; uttyára kgd? valoe (Bosz. 2: 346. sz.).

Problematikusak ugyanakkor azok a szövegrészletek is, amelyek latinul vannak (például az egész kérdést tagadja: Negat per totum, már forrásokban Negative); hiszen ez egyértelműen nem így hangzott el, ugyanakkor a vádlott saját szavai nem hozzáférhetők. Előfordul, hogy az adott kérdésnél olyan kiadói megjegyzést találunk: „Nincs válasz” (a kéziratban egyszerüen üresen hagyott részeket). Ezekben az esetekben szintén rejtve marad a szituáció - gondolva itt arra, hogy ha a kérdésre nem felel a vádlott, akkor annyiban hagyják-e, hogyan léptek tovább a következő kérdésre, mit akart ezzel leplezni a vádlott. A jelenleg vizsgált kihallgatási anyagban kommentár is jelzi, hogy nem a pillanatnyi beszédhelyzet rögzül: 1734: Ekor nem szóllot édgyetis, hanem a Tömlötzben zugolodott, kit mások halgattak (Bosz. 2: 346. sz.).

A salemi vádlottak kihallgatása kapcsán bizonyos szóválasztások (az egyik vádlott „,sweet heart”-ként szólítja meg a kihallgatást végző személyeket), vagy a szójátékok (bitch witch vagy wizzard - Buzzard) alapján feltehetö, hogy a lejegyzés pontos lehet, mivel ilyet az írnokok nagy valószínüséggel nem maguktól találtak ki (KAHLAS-TARKKA-RISSANEN 2015: 166). Összességében azonban (GRUND 2009 alapján) interpretációról és a szövegtípus nyelvi jellemzőiről beszélhetünk, ahol problematikus meghatározni, hogy a lejegyző mennyit alakított az elhangzottakon.

A továbbiakban elemzett szembesítéses kihallgatás formája párbeszédes. Az aktuális megnyilatkozókat - a természetes diskurzus hasonlóan - szinte mindig közvetlenül idézi a jegyzőkönyv, azaz a tanúvallomásoktól eltérően itt általában nincs külön tagmondattal jelezve a beszélőváltás (,kire X feleli”, ,arra Y mondja” stb.), kivéve Turos kihallgatásakor, 1734: A Disctrictualis Hajdu mondá ismét (Bosz. 2:346. sz. - a további idézetek is innen származnak). A lejegyzés rekonstruált jellegét mutatja, hogy a beszélőváltás időnként (talán a későbbi olvasót is szem elött tartva) igen explicit módon jelenik meg: Hijjak elö Gyulai Mihályt? Jelen vagyon immár. ${ }^{5}$ Jellemző az is, hogy mindig név szerint szólítják meg a vádlottat: Hát kgd Thót Gergelyné! mit mond ezek felöl; az új szereplők bevonását szintén

${ }^{5}$ SCHRAM FERENC kiadása szerint: Jelen vagyok immár, azonban a kéziratban (jelzete JNSzmL, IV., L., A., 1. 1734. 1. füzet, 1. kötet, 2. sz.) egyértelműen vagyon szerepel. 
így jelzik: Ugy vagyoné Kováts Gergely Uram és Simon János Uram. Ezek mellett több, a dialógus alakulására (egyezkedésre) vonatkozó - például témaváltást sugalmazó - megjegyzés szerepel: Tóth Gergelyné! No szollyon kgd a többirül és mire valok? Időnként megfigyelhető olyan formálisabb megoldás, amikor a válasz teljesen követi a kérdés formáját: Miböl vagyon tsinálva? Vagyon tsinálva: Bárány fadgyubol; Mire való a Diszno epe? A Diszno epe Pokolvarra valo [...], bár nem példátlanok az ennél szabadabban megfogalmazott reakciók sem (lásd 4.1.-4.2.). A természetes beszéd - és nem egyszer az indulatok - beszüremkedésére utal a számtalan nyomatékosító, diskurzusjelölő elem mind a vádlottak (biz én, biza, Oh Istenem, Isten áldja meg stb.), mind a kérdezők szövegében (ihol, hát, no hát, már mostan). Ugyanakkor egyes lejegyzői beavatkozások azonosíthatók: [Tóth Gergelyné:] szokasbol tartottam meg, etc. Hasonlóképpen a megszólított tanúk idegenes szóválasztása óvatosságra inthet a szövegformálás természetességét illetően: [,Ugy vané Bibo Uram? a mint eőkglme mondgya; és megis ölteé kgtek azt a szegény kigyot?"] Nem ugy van biz a nem is öltük meg hanem a mint én elébbis mondottam vala és azt Hittelis merem docéálni, melyrül az ulta nemis felejtkeztem, mert minden Esztendöben continualtam e felöl való emlékezésemet, beszélvén mindenek elött a kik e felében elöttem tsudálkoztak.

A jelenleg vizsgált szembesítés választását az is indokolja, hogy a kérdezők és a vádlott közötti egyezkedésre nagyobb a rálátásunk, mint a hagyományosabb kihallgatások esetében. Figyelmet érdemelnek ebben a tekintetben azok a kérdések, amelyek ugyanazt az eseményt, körülményt firtatják, azonban - esetleg részben átfogalmazva - újra és újra előkerülnek (jelezve, hogy a vádlott korábbi válaszait nem tartják az adott helyzetben megfelelőnek a vizsgálók). További szempont, a diskurzusstratégiákat és értelmezésüket hogyan befolyásolja a vád és az alapstratégia jellege (tagadás). Kérdés ezzel összefüggésben az is, hogy a kérdésekből és a válaszokból kirajzolódó diskurzus és az kikövetkeztethető egyezkedés nyomai megfeleltethetők-e az udvariassági modellek leírásainak (beleértve a salemi forrásokkal kapcsolatos megfigyeléseket a távolító udvariasságról).

\section{A szembesítést tartalmazó kihallgatási szöveg diskurzusstratégiáinak elemzése}

4.1. Az alábbiakban a bizonyítási eljárás azon szakaszáról beszélhetünk, amikor a vádlottaknak csak a megnevezett tanúk konkrét vádjaira kell válaszolni, valamint meghatározott tárgyi bizonyítékokkal kapcsolatban kérdezik ki őket. Az úgynevezett jóindulatú vallatás és a kínvallatás jellegzetes kérdései (lásd például SUGÁR 1987: 246-247) nem jelennek meg, még a vádlottak adatait sem veszik fel. A kérdezőkkel folytatott párbeszédbe pedig további személyek vonódnak be, mindez egyfajta párbeszédes (kérdés-válasz szekvenciák) formájában jelenik meg. Mind a felépítés, mind a feltett kérdések jó alapot adnak arra felvetésre, hogy hasonlóan nyilvánulnak-e meg a magukat ártatlannak tartó vádlottak, mint a salemi kihallgatásokban, vagy sem, és ez utóbbi mivel magyarázható. A viselkedési stratégiákat, a benyomáskeltést tekintve az itt tárgyalt anyagban nincs olyan vádlott, aki elismerné a rontással, boszorkánysággal kapcsolatos vádakat. 
A jelenleg vizsgált anyagban szinte minden vádlottat szembesítenek egyes tárgyi bizonyítékokkal is, melyeket (elvileg) az ő portékáik között találtak. Azonban több vádlott is azt állítja, hogy nem ismerik fel, illetve nem vallják magukénak a tárgyakat. Gál Andrásné ellen: Nem tudom nem enyim én nem is láttam, ki mit tsinált vélle maga tudgya; Némáné ellen: Némáné! Mire való ez az Atzél Tükör? $\mathrm{Nem}$ tudom mert nem enyim. Tóth Gergely ellen: de a tobbit nem ismérem, a Feleségem is mire tartotta nem tudom. A választ elfogadva ekkor a feleséget is külön kikérdezik (szintén nem sok eredménnyel). Az szituációs kontextusból nem derül ki, hogy valóban nem az ő tulajdonaik kerültek elő, vagy az elhallgató attitüddel a gyanúsítást akarták kivédeni. A vizsgálók már ekkor is megszólítanak olyan tanúkat, akiket a vádlottak emlegetnek, például Tóth Gergely felesége egy tárgyi bizonyíték kapcsán: Görbe Susa! kgd adtaé ennek az aszszonynak ezt a szap tojást? Nem adtam biz én édes Uraim! Soha sem láttam nemis emlékezem réá, ébre fogja eőkglme. A vádak bizonyítása e téren szubjektívnak tünik, ugyanis gyakran nem derül ki, hogyan viszonyulnak azokhoz, akiket - mint az elöbbi esetben is - hazugságon vagy ellentmondásos válaszadáson kaptak (a lejegyzés - a hozzáférhető kézirat - alapján ugyanis ezeket a kérdéseket nem kérdezik újra, nem fogalmazzák át).

A vádlottak szembesítő diskurzusait kisebb csoportokban fogom tárgyalni, egyrészt a stratégiák, másrészt a vádak alapján. Az első csoport ténylegesen több személyből áll, esetükben szó van babonás orvoslásról, rontásról, nyargalásról, valamint babonás(nak tartható, gyanús) szerek, tárgyak tartásáról. Az első csoportot a vádak mellett az köti össze, hogy az orvoslást általában beismerik, föleg családon belül - gyakran az ezzel kapcsolatos tárgyi bizonyítékokról is részletesen beszámolnak: A Diszno epe Pokolvarra valo, ki hasittyák és vészik, réá tétetvén a Pokolvarra, nem hadgya a mérgit meszsze terjedni. Hős Panna például a rontás vádját egyértelmúen tagadja, azonban az orvoslás eszerint más megítélés alá esik: én soha semmi Boszorkányságot sem üztem, ötet sem bántottam; hanem szem gyogyittást, azt nem tagadom, tselekedtem. A gyógyítás és az azzal összefüggő eszközök kapcsán közös és lényeges attitüd mutatkozik meg: hangsúlyozzák, hogy a közösségben ez teljesen bevett, semmi rendkívüli vagy gyanakvásra okot adó nincs benne: [Tóth Gergelyné:] mondotta, hogy (jo a Leányomnak az égy féle (:vagy ho:) szám ellen. [...] A többi is mind holmi orvossagnak valok a mint mások javasolták, azért tartottam; [Gál Andrásné:] A Léányomnak tsináltam, az egy féle nyavalya ellen, orvoslottam vélle; [Deák Miklósné:] többit is mind hol mit orvoslani tartottam a mellyek valának. Ez a hozzáállás más babonásnak számító holmi kapcsán is megjelenik: A köldök formakat mint mások szokasbol tartottam meg. Külön megszólított tanúk is megerösítik, hogy ez ekkoriban nem szokatlan: Enyim, én tartottam meg mindenik gyermekemét mint másokis szokták a kiket tudok.

A többi vád tagadása mindenkinél egyértelmü, egyúttal megjelenik a vallásosság, a jámborság hangsúlyozása: [Gál Andrásné:] Én láttya Isten nem tselekedtem, büntelen vagyok erre a vádra. Ezúttal azonban, mivel az ördöggel való szövetség tagadása a cél, nem számít „nem helyénvalónak”. Emellett a vizsgálók lejegyzésre méltónak találják, hogy jelezzék a vádlottak érzelmeit, például Hős Panna esetében: Tagadom azt az én Istenem elött (:sirva szóll:). Vannak azonban öntudatosabb válaszok is, mind Deák Miklósnéé, akit mindössze a tárgyaival szembesítenek 
(ezúttal tanúkat nem kérdeztek ki). Ő a babonásnak is tekinthető eszközökkel kapcsolatban próbálja meggyőzni a vizsgálókat: édgyik sem jár az ördögséggel edés jo Uraim. Ebben az esetben nem egyértelmü, hogy ez a bizalmas megszólítás az eljárás formálisabb szituációja miatt agresszívnek számít, vagy egyfajta együttérzésre építő udvariasságként a meggyőzés részének tekinthető (vö. a salemi anyagokon végzett kutatások szerint a bizalmaskodás az agresszív viselkedés része).

Időnként a tanúkéhoz hasonló hiedelmek is megjelennek; Gál Andrásné például az alábbi megjegyzéssel tagadja a rontás vádját: ám ha valaki tselekedte az én képemben, talam meg lehetett. A mások alakjában való rontás lehetősége tehát erős és általános vélekedés lehetett a közösségben. Más kérdésben pedig ugyancsak tájékozottnak mutatkozik a rontás lehetőségeivel kapcsolatban: nem is tudom mire gondolhattya eökglme hogy én rontottam vólna; holott Tehenem nincs a mire hasznát is el vehettem vólna. Hős Panna későbbi kihallgatása során öntudatosabban mutat rá a tanú/kárvallott megbízhatatlanságára és a vád hiteltelenségére: „Oláh István réám fogta hogy sót hoztam rajta, holott hiszem részeg vólt, a mint a szomszédgyiis mondották hogy az ágyról is lé esett öszve rontotta magát, még is tsak réám fogja ártatlan vóltomra". Ezúttal az alakváltásra is rákérdeznek, erre szintén nyomatékos tagadás a válasz: Ugy mondgyák Farkas is vóltál? Nem vóltam biz én sohais.

4.2. Az eddig idézett vádlottak többé-kevésbé részletes és megfelelönek számító módon (együttmüködően) válaszoltak a kérdésekre. A szövegközlés és a kézirat alapján eddig kevésbé látszanak olyanfajta egyezkedés nyomai, amelyek másfajta stratégiákra engednének következtetni. Némáné ügye azonban különlegesnek bizonyul. A tárggyal való szembesítésnél ugyan tagad, de mostohafia szokatlan vádjára - égykor kgd szabaditotta meg a Boszorkányok igája alol -, kitérő válaszokat ad: Az Isten áldgya meg a jó Fiamat, hogy mégis mentségemre szoll, mert énnékem jó Fiam vólt, és mindenkor Édes Anyám Aszszony vólt az én Nevem, az Isten áldgya meg, és ha jót tselekedtem akor nem egyebért tselekedtem, az Isten áldgya meg.

Azt, hogy a kérdezők elégedetlenek a válaszokkal, egyértelmüen mutatja az a mód, ahogy a kérdést átfogalmazzák, többször, többféle módon rákérdeznek: Juté esziben kgdnek ez a dolog? Jut hogyne jutna Isten áldgya meg. A részletekbe - kik voltak a boszorkányok - is hiába kérdeznek bele: Nem tudom Sziveim! nem is mondhatok senki Anya Fia Leánya ellen! Ezek után a kérdezők áttérnek egy másik ügyre, a szinte állításszerü kérdéshez gúnyos felszólítás is társul, mintha elvesztenék a türelmüket: Katona Jánost is nyargalta kgd, jó paripája vólt kgdnek, ditsérje kgd már aztis? Ezúttal azonban egyértelmü és határozott tagadás a válasz: Aha de hogy nyargaltam, nyomorúlt Vén vagyok, akar ki nyargalta de én nem nyargaltam! Némáné esetében is hangsúlyosak az érzelmek, a hívőség, jámborság kimutatása (a sokszor ismételt Isten áldja meg), ráadásul együttérzést is kelthetett azzal, hogy magára nyomorultként utalt. Egyedül Némáné esetében kerül elő később is a tárgyi bizonyíték („köldökformák”), ezúttal ellentmondásba is kerül a korábbi válaszával: A Baba mondotta hogy tartcsam meg hiszem nem árt ez. Magham gyermekeie vóltak (míg korábban nem ismeri el a sajátjának). Némáné a későbbi válaszaiban is ellentmondásosan számol be az eseményekről: „Mit tsinaltal a Malomban Legyeket őrleni miért mentél? Bizony nem tudom mentemé vagj ném. [...] Mitsoda dologban jártál ott a malomnal. Nem égyébért, hanem hogy a Fiamat meg szabadittsam". 
Ahogy látszik, a kérdezők ezúttal is szükségesnek látják, hogy többször rákérdezzenek ugyanarra az információra, mivel Némáné a továbbiakban sem ad világos válaszokat: „Hogy szabaditottad meg a Fiadat? Györe Jánost a malomban. Jól tettem vélle hogy meg szabaditottam [...] Örölteké a Fiadon? Örlöttek. Mit őrlöttok a fiadon s kik? Nem tudom". Ezúttal annyi kiderül az ügyről - s itt a fiára hivatkozik tanúként -, hogy a boszorkányoktól való megmentés annyiból állt, hogy megszólította a fiát: Maga móndgya hogy hamar osztán meg virradt és hogy kiáltottam mit tsinálsz itt té János. Noha a „szabadítást” elismeri (Magam ha az életemet el vesztem is meg vallom), az ördöggel való szövetséget és a boszorkányos tudást határozottan és egyértelmủen tagadja, s ezúttal sem vádol meg másokat boszorkánysággal: Nem tudtam nem ismértem többet hanem a Fiamat és meg szollitottam: Mit tsinálsz itt te Jancsi? [...] Nem tudom ment már akkor a malomban be vólt fogva a Fiam és ha tudtam vólna hogy ennyire lesz dolgom be mentem vólna inkább a malomban akkor. Ugyanakkor - más vádlottaktól eltérően - nem próbálja hitelteleníteni a fia vallomását, inkább saját magával kerül ellentmondásba.

4.3. Újabb diskurzusstratégia és attitüd mutatkozik meg Turos István esetében, aki a boszorkánysággal való rágalmazás vádjával is elkülönül. A vizsgált anyagban egyedi jellemzője ennek a stratégiának, hogy a vádlott kifejezetten az eljárást lefolytató hatóság ellen fordul. Tényszerüen közlik a vádat a kérdésben (Mire nézve mondotta kgyd a Szegedi Birot és Halasi Eskütteket Boszorkannak?), a vádlott ugyanakkor indulatosan reagál, bizonyítékot követel: En tagadom, en nem mondtam, vallya szememben a ki hallotta töllem. Noha a vizsgálók felemlegetik a tanúkat (Ihol Notarius, Hertzeg, Beszermenyi Urék merik mondani), s átfogalmazzák a kérdést (miert kellett tselekedni?), továbbra nem jutnak közelebb a válaszhoz. A vádlott ugyanis - mintha szerepet akarna cserélni a vizsgálókkal másik ügyet idéz fel, és cselekvésre szólítja fel a hatóságot: engemet is annak mondottak [...] keresse réá kgtek azt is! Mikor azonban rámutatnak a vizsgálók, hogy éppen tỏle várnak bizonyítékot - Hiszem lám keressük mondgya hat kgd s nevezze [...] itt valot mondgyon kgd valakit? -, a vádlott lényegében visszakozik: Nem tudok biz én senkit is! Miután ezzel saját magát hiteltelenítette, ezzel az ügy tulajdonképpen értelmetlenné válik, ezt azonban a vizsgálók sem hagyják szó nélkül, egyúttal egyértelmủvé téve a hatalmi viszonyokat: Hát mit haszontalankodik kgd, kgd igen bölts embernek tartya magát ugy latszik. Az indulatos, szubjektív (haszontalankodik) és gúnyos megjegyzés ellenére a korábban említett rágalmazási esetet is tisztázzák, további tanúk bevonásával, mivel Turos ismét a hatóság intézkedéseit - annak hiányát - kritizálja: Mondottam mert lám Kováts Gergely, és Simon János Uraimat is, Gyulai Mihály eléggé le Boszorkányozta majd öt esztendeje még is az últa nem keresték eőkglmek. Azonban ez a vizsgálat sem lesz bizonyító erejü, mivel a felek csupán arról tudnak beszámolni, hogy már korábban tisztázták a helyzetet: tréfából tselekedtem, és ekkor hiszem mindgyárt én eökglmeket arrol meg követvén és megis békéllettünk. Ráadásul, mintegy a vádlott megnyugtatása érdekében nyomatékossá teszik (iróniától nem mentesen), hogy az akkori rágalmazás sem volt érvényes: Hát Gyulai Uram tudé $\mathrm{kgd}$ valami Boszorkányságot eokglmetek iránt mondani Túros elöttis. Nem tudok bizén nem is tudtam, lam mondom hogy boros lévén tsak trefalodtam kglmekkel. 
A stratégiákat tekintve azt mondhatjuk, hogy míg Salemben az együttmüködés része lehetett mások megvádolása boszorkánysággal, a hazai gyakorlatban ezt eltérően kell értelmeznünk. Ezúttal a megítélésben szerepe lehetett annak is, hogy a halasi tanácsra és más befolyásos emberekre vonatkozott a vád. A boszorkányok ,felismerése” a bűnrészesség gyanúját vonhatja maga után, ahogy az egyik tanú meg is fogalmazza: Bizony ugy tartyák ezt a Turost mint Boszorkányok Zászlotartoját.

4.4. Egy további stratégiasor mutatkozik meg Bangó Ferenc szembesítésekor. Nála is alapvető álláspont a tagadás, de az első csoporttal ellentétben semmit nem ismer be egyértelmüen. Ebben a tekintetben talán ö állítható a legközvetlenebbül párhuzamba a salemi szúkszavú és agresszív vádlottakkal. Amikor ugyanis a vizsgálók valamiféle bizonyítékra (jellemzően tanúk korábbi beszámolóira) hivatkoznak, és annak értelmében újra rákérdeznek a vádpontra, akkor sem egyértelmü válaszokat kapnak a vádlottól, mint Meg lehetett! Nem tudom! vagy - annak kapcsán, hogy nem engedett egy beteget meggyógyítani-Miért nem engedtem volna! Más esetekben pedig nem pusztán tagad, hanem további öntudatos megjegyzésekkel hangsúlyozza igazát: Mire valo én sem tudhatom, mivel talám sóha életemben sem láttam édgiket is, vegye hasznát a kie ez után is.

Ahogy a viszonylag együttmüködő vádlottaknál is megfigyelhetö Isten emlegetése a tagadás kapcsán, ez Bangóra is jellemző: Oh Istenem! én bizony nem nyargaltam; Oh Istenem (:sirva szoll:) ha vólt az, Jésus Chiristus Jesus Christus hisz én nem tselekedtem azt is! Sőt még az egyik tanú hitelességével kapcsolatban is megjelenik érvként a hit: Balog nem felszé az Istentöl. Az ö beszédének lejegyzésében is megjelenik ugyanakkor a sírásra vonatkozó metakommunikatív megjegyzés. Ezzel együtt egy újabb, agresszívnek is tekinthető stratégiával él a vádlott, ez azonban nem közvetlenül a vizsgálók ellen irányul. Elsősorban ugyanis a tanúk hiteltelenségét emeli ki megszólalásaiban: „Mondgyon a Jánbor, de én azt a Liba felett való veszekedest sem tudtam meg edig is soha”; „én bizony nem nyargaltam tsak álmadozott őkglme akkor". Az eljárás hagyományos menete is felbomlani látszik, mivel időnként a vádlott - mintha szerepet cserélne a kihallgatást végző hatósággal - maga szólít meg tanúkat, közvetlenül tagadva az állításaikat: Balog nem felszé; „Engem nem kergetett Patai Pál te sem láttad”. Ugyanakkor a hatósági személyek is megszólítanak egy korábban nem kérdezett tanút (Hijjak Vékei István Uramat); ez a szembesítés a vádlott igazát támasztja alá, a megszólaló ráadásul a vádlotthoz hasonlóan nyíltan kiszól egy korábbi tanúhoz: másként én vélem magát a Jámbor edgyikis ne igazittsa. Albert János té ébben bizonyitts egyébről. - Bangó későbbi kihallgatása nagyobb együttmüködésre utal: részletes információval szolgál arról, mi kelthette az ő esetében boszorkányság gyanúját. Nem a korábbi vádakat hozza fel, hanem hogy jó ideje ismeretségben volt a Szegeden megégetett Rózsa Dániellel: ha Szögheden dolghom vólt hazahoz szallottam, s ha nekie itt járása volt nalam szallott; ily velekedesbül foghtak megh.

Bangó kapcsán is megjelenik a boszorkánysággal rágalmazás vádja, ő azonban a közösségben bevett érveléssel védekezik: Ugy mondottam, hogy ha én Boszorkány vagyok öis Boszorkány, nem mondottam másképpen, mert öis le szidott engemet. Ez a fajta hozzáállás egy másik vádlott, Turos esetében is előjön: Azt 
mondottam biz én hogy Boszorkány az a kit annak mondanak, ha réá nem keresi - de általánosabban, más eljárások kapcsán is megjelenik. A közösségi hiedelemnek és hozzáállásnak ismeretében indokoltnak tekinthető, hogy Túros ebben a szituációban már hárít és tagadja „képességét”, hiszen így is tömlöcbe került. A külön megszólított tanú hasonlóan elhárítja az ilyesmit: [...] majd Társas vólnék hát én igy Bango Ferentzel, ha én ötet Kapitánynak vallanám! Ezúttal tehát a tagadás egyaránt megvalósul szükszavú, kitérő válaszokkal, a vallásosság hangsúlyozásával, valamint - föként - rámutatva a tanúk megbízhatatlanságára. A vádlott igen öntudatosan nyilvánul meg a diskurzusban, időnként szinte átvéve az irányítást azzal, hogy közvetlenül ki-kiszól a tanúnak. Igaz ugyanakkor, hogy az egyik külön kérdezett tanú is hasonlóan ,merészen” viselkedik: Albert János té ébben bizonyitts egyébröl. Mivel a jegyzőkönyvben ezekre vonatkozó reflexiókat a hatóság részéről nem találunk, ennek megítélése nem egyértelmü. Ugyancsak nem kétségtelen a hasonlatok, a képszerü érvelés megítélése. Bangó Ferencnél is megfigyelhető az ilyen reakció: tsak rám foghnak már mindent mint a mely ébnek veszett nevit költik. A vizsgált anyagból kitekintve sem példátlan a hasonlattal érvelés: 1759: [„Hát te ilyenformán mindenekben ártatlan vagy?”] Olyan ártatlan, mint a mai született gyermek (MBF. 4: 465); holott olyan büntelen vagyok, mint a mai született gyermek (MBF. 4: 466); 1766: Ebböl a dologbul tiszta vagyok, mint a napfény (KOMÁROMY 704). Az idézettek megítélését nehezíti, hogy nincs rájuk vonatkozó explicit visszajelzés, negatív következmény az eljárásban.

A vádak többségének tagadása nem jár együtt az (a korszak és a szövegtípus szempontjából átértelmezett) együttmúködés hiányával. A vádlottak ugyanis részletes és tájékoztató jellegű válaszokat adnak például a gyógyításra használt eszközök kapcsán. Eltérő vádak esetén - mint a rágalmazás vagy a boszorkányoktól megszabadítás - ugyanakkor a stratégiák is mások. Némáné például hosszabb, de sajátságosan kitérő válaszokat ad, a kérdezők által kezdeményezett egyezkedés (újrafogalmazott kérdésekkel) pedig majdnem teljesen sikertelen - az első kihallgatáson nem is derül ki, mit is neveznek a kérdésben „megszabadításnak”. A vádlottak közül általában a férfiakra (Turos István és Bangó Ferenc) jellemző az (a szükszavú válaszok mellett), hogy a vizsgálódás szituációjából eredő egyenlőtlen hatalmi helyzeten változtatni próbálnak. Turos például tanácsot ad a vizsgálóknak, szemrehányást tesz a vizsgálóknak, bizonyítékot követel, zúgolódik a tömlöcben. Bangó pedig többször is az ellene valló tanúk hiteltelenségét próbálja bizonyítani azzal, hogy ki-kiszólogat feléjük (egy külön megszólított tanú segítségével talán sikerül is). Ó ugyanakkor nem kérdőjelezi meg a vizsgálók igazságosságát vagy ítélőképességét, mindössze egyszer kérdez vissza. A kérdezőkkel szemben tehát kevésbé tünik udvariatlannak, mint salemi sorstársai, még ha közvetlen kiszólásaival részben átveszi is a diskurzus irányítását (ez a megszólított tanúk esetében sem példátlan).

Noha a vádlottak időnként határozott- kioktatónak is minősíthető - válaszokat adnak a szembesítés során, nem jellemző rájuk sem a nevetés, sem az irónia és/vagy szarkazmus. Ha megjelenik hasonló attitüd, az a kérdezőkhöz kötethető, az egyenlőtlen hatalmi helyzet tudatában, bár nem mindig érnek célt ezzel (kitérö válaszokat kapnak), míg mások valószínúleg kénytelenek elfogadni a „lepirongatást”. Ez a fajta „hiány” a vádlottak jó helyzetfelismerő képességéről árulkodhat, 
mivel ezen a téren tiszteletben tartják az erőviszonyokat. Az anyagból kitekintve nem példátlan a vádlottak megnyilvánulásában felsejlő irónia, amikor rákérdeznek, honnan tudja a vádlott, hogy a boszorkány galamb és bárány képében nem tevékenykedhet, 1755: Deákos Embereknek jobban kell tudni (Bosz. 1: 95. sz.). A jelenség megítéléséhez több adat szükséges.

5. Kitekintés, záró gondolatok. Összességében elmondható, hogy a vádlottak kihallgatásai mind a diskurzusmintákat, mind a történetmondást tekintve külön alcsoportot - ezáltal összehasonlítási alapot - alkotnak a perszövegek szövegtípusán belül. A benyomáskeltés időnként igen direkt módon valósul meg az eljárás során ahogyan a vádlottak a saját személyükre reflektálnak. Időnként az önreprezentáció megfelel a tanúvallomásokból kikövetkeztethető közösségi képnek, felidézve a különféle konfliktusokat, az összeférhetetlen természetet: 1755: s akkor meg nehezteltem vólt reá [...] Való hogy nehezteltem Vincze Pálra [...] s megis haragudtam reá az eö beszédéért [...] Azért fenyegettem mert maga adot okot reá (Bosz. 1: 100. sz.). Jellemzőbb azonban az, hogy a vádakat cáfolandó, jámbor képet mutatnak magukról a vádlottak. Az sem példátlan, hogy kifejezetten naivnak, együgyünek próbálnak látszani - mivel a boszorkányság egyfajta tudásként jelenik meg: 1755: Az Imadsaghot sem tudom jól, nem hogy mást tudtam vólna megh tanúlni (Bosz. 1: 95. sz.); 1699: Miért vallál rám ártatlanul, hiszen a Mi Atyánkot is nem tudom igazan, (Bosz. 1: 17. sz.). A tanúk pedig időnként szavahihetőségükre hívják fel a figyelmet.

Az elemzés előtt feltett kérdésre - számított-e a vádlott nyelvi viselkedése az ügy kimenetelében - továbbra is csak óvatos választ, válaszokat lehet adni. Annyi bizonyos, hogy a rontás vagy akár a rontási szándék beismerése nem számított sikeres stratégiának, nem úgy, mint Salemben. A tagadás még szükszavú formában is eredményesebb volt, mint a boszorkányság beismerése; a salemi anyag kutatóival ellentétben a magyar forrásokban ez nem minősül agresszívnek. Ezzel együtt - a salemi gyakorlattól szintén teljesen eltérő módon - a gyógyítás nem számított feltétlenül elítélendő vádnak, főként azt hangsúlyozva, hogy sem a vádlott ezen tudományában, sem az ahhoz kapcsolódó eszközökben, nincs semmi rendkívüli. Ez ugyanis megfelelt a mindennapi közösségi ismereteknek, felfogásnak. Ez azzal magyarázható, hogy bármilyen bizonytalan létformáról van is szó, a korszakban a laikus gyógyítás általános volt, a falusi életmód természetes és tulajdonképpen nélkülözhetetlen része (részletesen lásd R. VÁRKONYI 1990; KLANICZAY 2014).

Több olyan stratégia, megnyilvánulás is megfigyelhetö, amely a párhuzamos forrásban is jelen van, a megítélésük azonban a kontextus miatt eltér az ottanitól, ilyen például az istenfélőség, vallásosság kifejezése. A magyar anyagban Isten és Jézus emlegetése elsősorban a gyógyítás kapcsán jelenik meg, jelezve a babonásnak tünő tevékenység ártalmatlanságát, míg Salemben a kérdezők ellen irányuló támadó retorika része - erre nálunk egyelőre nincs példa (arra igen, hogy a tanúkon kérik számon istenfélő voltukat). Mivel a magyar eljárásban az ártatlanságot kell bizonyítani, és általában a tagadást nyomatékosítják ezek a felkiáltások, ezzel a vádlottak jámborságukat (és/vagy érzelmi megrázkódtatásukat) fejezik ki. A boszorkánysággal való vádaskodás eltérő értelmezése - sorstársnak, így bűnrészesnek minősülnek - szintén a közösségi, kulturális szempontokkal magyarázható. 
További stratégiák értelmezését kell újragondolni a magyar források tükrében, főként az udvariasság és a verbális agresszió mentén. Salemben agresszívnek, udvariatlannak minősül a képszerüség az érvelésben - nem egyértelmü, hogy visszavetítve, annak tudatában, hogy az így megnyilatkozó vádlottakat elítélik. A magyar forrásokban ezek megítélése a rájuk vonatkozó reflexió hiányában nyitott marad (az udvariatlanságként értelmezés mindenesetre kétséges). Salemben az is udvariatlannak, de legalábbis merésznek számít, amikor az egyik vádlott sweetheart-nak szólítja a kérdezőket (miközben épp tagadja a vádat). A magyar vádlottak szövegében is megmutatkozik időnként a bizalmasabb szóhasználat, azonban nem a sikertelen stratégiák mellett. Mivel Némánétól és Deák Miklósnétól jegyeztek le ilyen megjegyzéseket, akár egyszerüen az idős nők természetes (bizalmas, kedveskedő) szóhasználatának részének is tekinthetők. A szituációhoz képest bizalmas szóválasztás pedig a szembesítéskor megszólított tanúknál sem példátlan. Problematikus lenne eldönteni (a mai nézőpontból és elvárásokból kiindulva) ezeknek a helyénvalóságát, főként, hogy a jegyzőkönyvben nincs rájuk vonatkozó közvetlen visszajelzés. Joggal merül fel, hogy a salemi gyakorlattól eltérően nem a távolító, hanem a közelítő, együttérzésre, bizalmasságra alapozó udvariasság nyomait látjuk-e a szövegeken (ha igen, úgy érthető, hogy a kérdezők nem kérik számon a vádlottakon és a tanúkon ezt a viselkedést). A hatóság szóhasználata is szubjektív időnként, olyannyira, hogy a hiedelmek, közösségi vélekedések (szokatlan, rendkívüli, tehát gyanús) is megmutatkoznak a szóválasztásban (tsudássan van tsinálva; igen jó Varaslo orvos). A jogi diskurzusban helyénvalóság határai mindenesetre máshol húzhatók meg, mint napjainkban, így a bizalmasság rugalmasabb kezelése részben ezzel is magyarázható. Az azonban további vizsgálatokat igényel - az itt tárgyalthoz hasonlóan reflexív jellegü források bevonásával -, hogy a közelítő udvariasság lehetett-e az általános a szövegtípusban, s ez összefügg-e a kulturális különbségekkel (legföképpen azzal, hogy az ártatlanságot, a közösséggel együttmúködő viselkedést kellett a vádlottaknak bizonyítani).

Kulcsszók: boszorkányperek, kihallgatási szövegek, kommunikációs kontextus, pragmatika, középmagyar korszak.

\section{Hivatkozott irodalom}

Bosz. $=$ Magyarországi boszorkányperek 1529-1768. 1-3. Közreadja: SCHRAM FERENC. Akadémiai Kiadó, Budapest, 1970-1983.

Chaemsaithong, Krisda 2009. Re-visiting Salem. Self-face and self-politeness in the Salem witchcraft trials. Journal of Historical Pragmatics 10: 56-83. https://doi. org/10.1075/jhp.10.1.04cha

CulPePER, Jonathan - Semino, Elena 2000. Constructing witches and spells: speech acts and activity types in Early Modern England. Journal of Historical Pragmatics 1: 97-116. https://doi.org/10.1075/jhp.1.1.08cul

DÖMÖTÖR AdRIENNE - GUGÁN KATALIN - NOVÁK ATTILA - VARGA MÓNIKA 2017. Kiútkeresés a morfológiai labirintusból - korpuszépítés ó- és középmagyar kori magánéleti szövegekböl. Nyelvtudományi Közlemények 113: 85-110. https://doi.org/[-] 10.15776/NyK.2017.113.3 
GRUnd, Peter et. al. 2009. Linguistic introduction. In: Rosenthal, BERnARD gen. ed. Records of the Salem Witch-Hunt. Cambridge University Press, Cambridge. 64-89. https://doi.org/10.1017/9781107589766

Hiltunen, Risto 2010. Discourse and context in a historical perspective. On courtroom interaction in Salem 1692. In: TANSKANEN, SHANA-KAISA et al. eds. Discourses in interaction. John Benjamins Publishing Company, Amsterdam (Philadelphia). 61-78. https://doi.org/10.1075/pbns.203.06hil

Kahlas-TARKKA, LeEnA - Risannen, MatTi 2007. The sullen and the talkative. Discourse strategies in the Salem examinations. Journal of Historical Pragmatics 8/1: 1-24. https://doi.org/10.1075/jhp.8.1.02kah

KAHLAS-TARKKA, LEENA 2012. „I am a Gosple Woman”: On Language in the Courtroom Discourse during the Salem Witch Trials, with Special Reference to Female Examinees. Studia Neophilologica 84. (Sup.1.): 55-69. https://doi.org/10.1080/00393274.[-] 2012.675635

KAHLAS-TARKKA, LEENA - RiSANNEN, MATTi 2015. “Oh! you are liars, \& God will stop the mouth of liars": Impolite and aggressive discourse in Salem witchcraft trial examinations 1692. In: Ulla TUOMARLA et al. eds. Miscommunication and Verbal Violence. Société Néophilologique de Helsinki, Volume 93., Helsinki. 153-168.

KLANICZAY GÁBOR 2014. Gyógyítók a magyarországi boszorkányperekben. In: KLANICZAY-PÓCS sZerk. 263-305.

KLANICZAY GÁBOR - PóCS ÉVA szerk. 2014. Boszorkányok, varázslók és démonok Közép-Kelet-Európában. Balassi Kiadó, Budapest.

KOMÁROMY = Magyarországi boszorkányperek oklevéltára. Közreadja: KOMÁROMY ANDOR. Magyar Tudományos Akadémia, Budapest. 1910.

KonCZ IBOLYA KaTALin 2007. A boszorkányüldözés jogtörténeti kérdései a Német-Római Birodalomban és a Királyi Magyarországon. PhD értekezés, Miskolc.

Sz. KRISTÓF ILDIKÓ 2014. Boszorkányüldözés a kora újkori Magyarországon: kutatástörténet, eredmények, teendők - 2013-ban. In: KLANICZAY-PÓCS szerk. 17-62.

MBF. 4. = A magyarországi boszorkányság forrásai 4. Szerk. TÓTH G. PÉTER. Balassi Kiadó, Budapest, 2005.

NEMESI ATTILA LÁsZLÓ 1997. Miként viselkedünk a szavakkal? Benyomáskeltés és nyelvhasználat. Magyar Nyelvör 121: 490-496.

NEMESI ATTILA LÁSZLÓ 2000. Benyomáskeltési stratégiák a társalgásban. Magyar Nyelv 96: 418-435.

PóCS ÉvA 1983. Gondolatok a magyarországi boszorkányperek néprajzi vizsgálatához. Ethnographia 94: 134-147.

Rissanen, Matti 2012. Power and Changing Roles in Salem Witch Trials: The Case of George Jacobs, Sr. Studia Neophilologica 84. (Sup.1.): 119-129. https://doi.org/[-] 10.1080/00393274.2012.668079

SUGÁR ISTVÁN 1987. Bübájosok, ördöngösök, boszorkányok Heves és Külsö Szolnok vármegyékben. Közreadja: SugÁR ISTVÁN. Magyar Tudományos Akadémia, Budapest.

VARGA MÓNIKA 2015. „Ezen szódnak ura légy!” - Megszólalásokról boszorkányperekben. In: BÁRTH M. JÁNOS - BOdó CSANÁD - KoCSIS ZsuzsANNA szerk., A nyelv dimenziói. Tanulmánykötet Juhász Dezső tiszteletére. ELTE BTK, Budapest. 143-154. 
R. VÁRKONYI ÁGNES 1990. Közgyógyítás és boszorkányhit (Mária Terézia boszorkánypereket beszüntető törvényének újragondolásához). Ethnographia 101: 384-432.

\section{On the communicative context of witcheraft trials}

The paper studies the context of communicative strategies in Middle Hungarian witchcraft trials, including the roles in court trials against witches and the linguistic behaviour associated with them, in interrogation protocols and via a detailed analysis of a complex process of taking evidence. The cultural role of a witch includes a characteristic pattern of linguistic behaviour. On the basis of the Salem witch trials of 1692-93 an inventory of the diverse types of defendants has been set up, together with the communicative strategies they tended to follow. However, on the basis of the extant verdicts and the literature of legal history, we can draw the conclusion that, during the Hungarian legal procedures, what was more successful in most cases was denial, rather than admission. The analysis of the texts highlights the ways a communicative strategy that would count as aggressive in any other situation can be reinterpreted in the context of Hungarian interrogations.

Keywords: witchcraft documents, trials, communicative context, pragmatics, Middle Hungarian period.

VARGA MÓNIKA ELTE Nyelvtudományi Doktori Iskola, MTA Nyelvtudományi Intézet 